\title{
EXTRACTION OF SUBSURFACE FEATURES FROM INSAR-DERIVED DIGITAL ELEVATION MODELS
}

\author{
Siting Xiong ${ }^{(1)}$, Jan-Peter Muller ${ }^{(1)}$ \\ (1) Imaging Group, Mullard Space Science Laboratory (MSSL), University College London, Department of Space \& \\ Climate Physics, Holmbury St Mary,Surrey,RH5 6NT,UK,Email: j.muller@ucl.ac.uk
}

\begin{abstract}
Microwave remote sensing has the potential to be a beneficial tool to detect and analyse subsurface features in desert areas due to its penetration ability over hyperarid regions with extremely low loss and low bulk humidity. Global Digital Elevation Models (DEMs) of resolution up to $30 \mathrm{~m}$ are now publicly available, some of which show subsurface features over these hyperarid areas. This study compares different elevations detected by different EO microwave and lidar profilers and demonstrates their effectiveness in terms of extraction of subsurface features compared with that delineated in ALOS/PALSAR polarisation map. Results show that SRTM-C DEM agrees closely with ICESat elevations and that SRTM-C DEM clearly show paleoriver features, some of which can't be observed in ALOS/PALSAR images affected by background backscatter. However, craterlike features are more recognisable in ALOS/PALSAR images compared with SRTM-C DEM.
\end{abstract}

Key words: DEM, Topographic features, Paleochannels, subsurface detection, mapping.

\section{INTRODUCTION}

Since 1972, when McCauley J. F. et al. [1] unveiled the subsurface valleys buried under a thin dry sand layer in the eastern Sahara by SIR-A, microwave imaging at low frequency (e.g. $1.25 \mathrm{GHz} / 24 \mathrm{~cm}$, L-band) has attracted a lot of interest as its potential to be able to map subsurface features in desert areas. Blom et al.[2] concluded that radar penetration occurs in environments where geological processes produce homogeneous, finegrained materials that cover a layer 1-2 m thick if the moisture content is less than about $1.0 \%$, and revealed subsurface igneous dikes buried beneath as much as $2 \mathrm{~m}$ of alluvium in the Mojave Desert of California in SEASAT radar images. Elachi et al. [3] proposed that a low-loss thin sand layer enhances the capability to image the subsurface sand-bedrock interface, particularly at large incidence angles and $\mathrm{HH}$ polarization. Over recent decades, further research has been facilitated since the launch of satellites with Lband SAR system onboard, such as the Japanese Earth observation satellites, JERS-1 and ALOS. An entire paleodrainage system and many craterlike features were reported by Paillou et al. [4, 5] in JERS-1 and ALOSPALSAR images. Based on archeological evidence and radar images, El-Baz [6] proposed that the sand dune in the eastern Sahara was brought in the depressions by paleo-fluvial and shaped by wind, and thus, the depressions must have hosted great volumes of surface water, which would have seeped into the underlying rock. However, there are very few studies who have looked into the potential of SAR for the detection of subsurface features in DEM elevations, and bedrock elevation mapping over hyperarid aresa by using DEM datasets. This is especially relevant with the advent of complete global Digital Elevation Models (DEMs) produced at different electro-magnetic wavelength ranges from spaceborne earth observation, such as microwave frequencies from SRTM (X- and C-band), TanDEM-X (X-band) and ALOS-PALSAR (L-band) as well as stereo-optical, such as ASTER or PRISM or lidars such as ICESat.

This study tries to investigate the effectiveness of DEMs, acquired at different wavelengths, to detect and measure subsurface features. We compare different surface expressions of optical images, SRTM-C band DEMs and ALOS-PALSAR polarisation images to show subsurface features, including paleorivers, craterlike circles, and sand covered bedrocks, over the eastern Sahara and the Ténéré Desert. Furthermore, detailed comparisons between DEMs along ICESat footprints and transects over subsurface features are shown over the Kufrah River and Gilf Kebir Plateau, two small study sites located in the eastern Sahara.

\section{STUDY AREAS}

The eastern Sahara in North Africa is one of the driest regions of the Earth, where the received solar radiation is capable of evaporating over 200-times the amount of rainfall [7]. However, geological and archaeological evidence indicate that it hosted much wetter climates in the past, when surface water appears to have been responsible for the erosion, transportation and deposition of sand into inland basins, which thus would have stored most of the water in the underlying porous rocks [6]. In this study, we choose the eastern Sahara and the Ténéré Desert, which are indicated by the two larger red rectangles in Fig. 1, as study areas to investigate these subsurface features. In the eastern Sahara, two smaller study sites, are the Kufrah River and Gilf Kebir Plateau, which are indicated by two smaller grey rectangles in Fig. 1. The Kufrah River is 
located in southeastern Libya, the study site covering an $11,000 \mathrm{~km}^{2}$ region between latitudes $23^{\circ} \mathrm{N}-24^{\circ} \mathrm{N}$ and longitudes $23^{\circ} \mathrm{E}-24^{\circ} \mathrm{E}$. There is a paleodrainage system, which passes through this region from south to east till Sarir Dalmah in Libya, which has been discussed in previous publications [5, 8]. The Gilf Kebir Plateau is located in southwest Egypt, where 1,300 craterlike features over $4,000 \mathrm{~km}^{2}$ were found by P. Paillou [4]. This study site covers a $23,000 \mathrm{~km}^{2}$ region between latitudes $23^{\circ} \mathrm{N}-24^{\circ} \mathrm{N}$ and longitudes $26^{\circ} \mathrm{E}-28^{\circ} \mathrm{E}$.

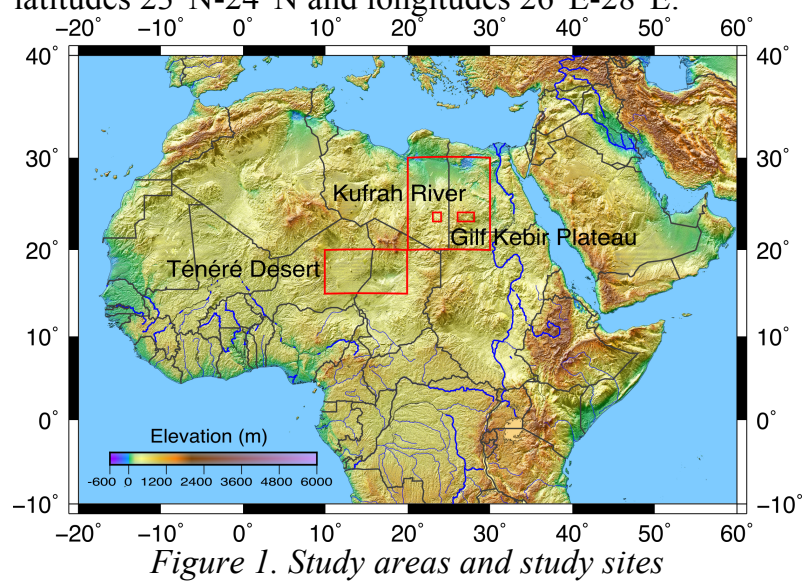

\section{DATASETS AND METHODS}

DEMs acquired by SRTM (X- and C-band), ASTER (stereo-optical) and ICESat $(1064 \mathrm{~nm}$ lidar) elevation data are utilised. The characteristic of each elevation dataset is listed in Table 1. In this study, SRTM-C DEM of 1 arc-second $(\approx 30 \mathrm{~m})$ resolution is employed to cover the eastern Sahara and the Ténéré Desert areas. These were publicly released in September 2014. ASTER GDEM v2 and SRTM-X DEM also cover the same two study sites. ICESat is the NASA Ice, Cloud, and land Elevation satellite, which has the Geoscience Laser Altimeter System (GLAS) instrument onboard and is aimed at measuring ice sheet elevations and changes with footprint of $70 \mathrm{~m}$ diameter every $150 \mathrm{~m}$ [9]. Its level-2 altimetry product (GLA14) provides surface elevations for land with accuracy to the centimetre level.

\begin{tabular}{|c|c|c|c|c|}
\hline & $\begin{array}{c}\text { ASTER } \\
\text { GDEM }\end{array}$ & $\begin{array}{l}\text { SRTM- } \\
\text { C DEM }\end{array}$ & $\begin{array}{l}\text { SRTM- } \\
\text { X DEM }\end{array}$ & $\begin{array}{c}\text { ICESat } \\
\text { /GLA14 } \\
\end{array}$ \\
\hline Tile size & \multicolumn{2}{|c|}{$1^{\circ} \times 1^{\circ}$} & $15^{\prime} \times 15^{\prime}$ & - \\
\hline $\begin{array}{l}\text { Posting } \\
\text { interval }\end{array}$ & \multicolumn{3}{|c|}{1 arc-second $(\sim 30 \mathrm{~m})$} & $\begin{array}{c}70 \mathrm{~m} / 150 \\
\mathrm{~m}\end{array}$ \\
\hline Datum & \multicolumn{2}{|c|}{ WGS84/EGM96 } & $\begin{array}{l}\text { WGS84/ } \\
\text { WGS84 }\end{array}$ & $\begin{array}{l}\text { TOPEX/ } \\
\text { Poseidon }\end{array}$ \\
\hline $\begin{array}{l}\text { Horizontal } \\
\text { accuracy }\end{array}$ & $\pm 20 \mathrm{~m}$ & $\begin{array}{c} \pm 20 \\
\mathrm{~m}(\text { abs. }) \\
\pm 15 \\
\mathrm{~m}(\mathrm{rel} .)\end{array}$ & $\begin{array}{c} \pm 20 \\
\text { m(abs.) } \\
\pm 15 \\
\text { m(rel. })\end{array}$ & $\begin{array}{c}2.4 \pm 7.3 \\
\mathrm{~m}\end{array}$ \\
\hline $\begin{array}{l}\text { Vertical } \\
\text { accuracy }\end{array}$ & $\pm 30 \mathrm{~m}$ & $\begin{array}{c} \pm 16 \\
\mathrm{~m}(\text { abs. }) \\
\pm 10 \\
\mathrm{~m}(\mathrm{rel} .)\end{array}$ & $\begin{array}{c} \pm 16 \\
\mathrm{~m}(\mathrm{abs} .) \\
\pm 6 \\
\mathrm{~m}(\mathrm{rel} .)\end{array}$ & $\begin{array}{l}0.04 \pm \\
0.13 \mathrm{~m}\end{array}$ \\
\hline
\end{tabular}

Due to different vertical datums with ASTER GDEM and SRTM-C DEM, SRTM-X DEM and ICESat/GLA14 data are all transformed into the same orthometric heights referenced to EGM96 datum. Horizontal offsets between ASTER, SRTM-X and -C band DEM were checked, these appear to be within one $30 \mathrm{~m}$ pixel. Although the ICESat/GLA14 data are referenced to a different ellipsoid cf. SRTM-C DEM and ASTER GDEM, the differences in geodetic latitude and longitude only produce a horizontal displacement of less than a metre, which can be ignored [9].

Besides DEMs, ALOS/PALSAR 25 m Forest and nonForest (FNF) map was used to delineate subsurface features. This product includes $\mathrm{HH}$ and HV backscatter, which is slope corrected and ortho-rectified using the SRTM, and then radiometrically de-calibrated. Japan Aerospace Exploration Agency (JAXA) has produced this 4-year, $25 \mathrm{~m}$ spaced global PALSAR mosaic from 2007 to 2010 using the accurate SAR processing. In this study, subsurface features are delineated by using ALOS/PALSAR HH backscatter acquired in 2010, which are shown in Fig. 2.
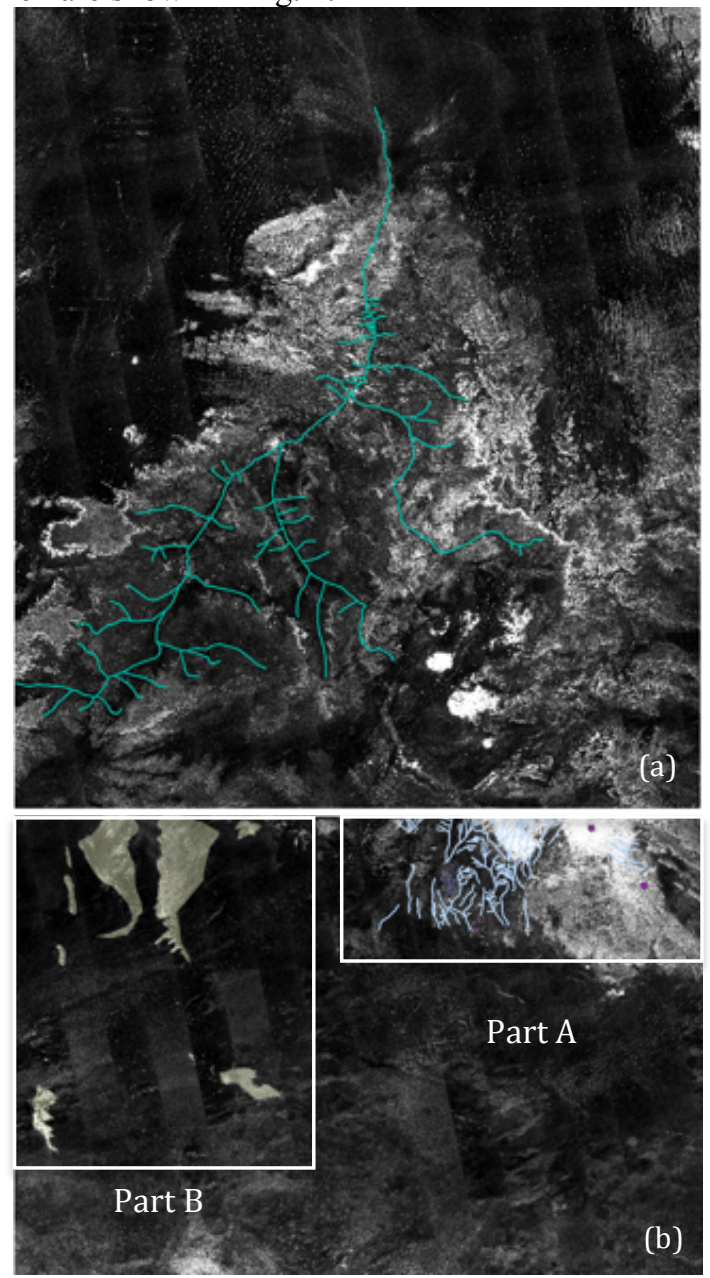

Figure 2. Subsurface features delineated by using ALOS-PALAR HH backscatter, (a) the eastern Sahara, (b) the Ténéré Desert showing 2 sub-areas 


\section{RESULTS}

Firstly, we show the extraction of subsurface features from different datasets over the eastern Sahara and the Ténéré Desert, including optical images, SRTM-C band DEM and PALSAR HH backscatter map. Secondly, different elevations from different datasets are compared against each other to show their potential for subsurface feature recognition over the Kufrah River and the Gilf Kebir Plateau.

\subsection{Extraction of subsurface features}

In this subsection, the two larger study areas shown in Fig. 1 are studied. The delineated features from ALOSPALSAR HH backscatter are laid over a Gaussian filtered, hill-shaded and mosaicked SRTM-C DEM and optical image (from Landsat) in Google Earth to demonstrate different surface expression from these three datasets. The extracted subsurface features in the eastern Sahara are shown in Fig. 3, while the Ténéré Desert features are shown in Fig. 4.

In Fig. 3, the blue lines show the ALOS-derived Kufrah river network as well as some circular features shown in the blue rectangle. From this figure, we can see the mainstream and tributaries agree well with topographic features on the SRTM-C DEM. The yellow rectangle centre insert shows the downstream alluvial fan of the Kufrah River, which is now covered by sand shown in Landsat image (left insert), while recognisable from both SRTM-C DEM and PALSAR image.

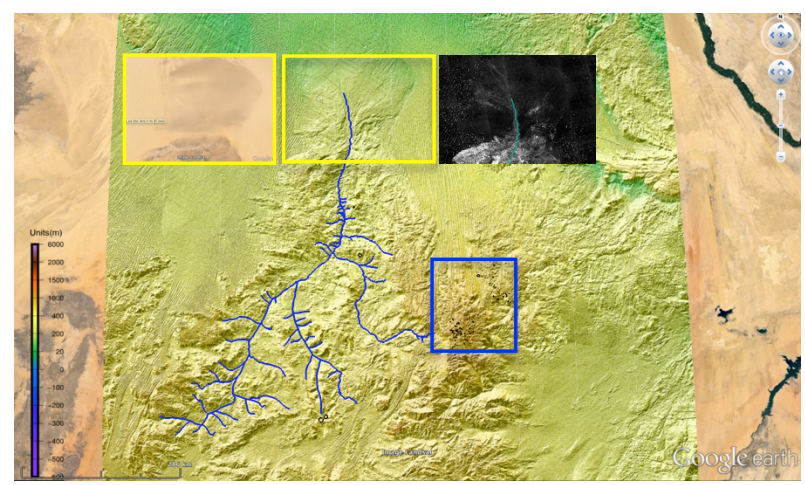

Figure 3. Subsurface features in the eastern Sahara

The study of the Ténéré Desert is divided into Parts A and B, which are shown in Fig. 4(a) and Fig. 4(b) respectively. The linear features are definitely subsurface features because they are hidden under sand in the optical image while clearly recognisable in both SRTM-C DEM and PALSAR image, which demonstrates the penetration ability of both $\mathrm{C}$ - and Lband microwaves. However, some tributaries cannot be delineated from PALSAR images, which may be due to confusion with similar low backscatter intensities as the background. As for circular features, few of them can be seen in the optical images, while most of them are shown in the SRTM-C DEM but less distinguishable than those in the PALSAR image. Part B of the Ténéré Desert in Fig. 4(b) indicates that the optical image only shows outcrop rocks shown in the blue ellipse, while SRTM-C DEM shows rocks with elevation different from background and different forms of sand cover, which is illustrated in the red ellipses. PALSAR image shows rocks covered under a thin sand layer, highlighted in the green ellipse.

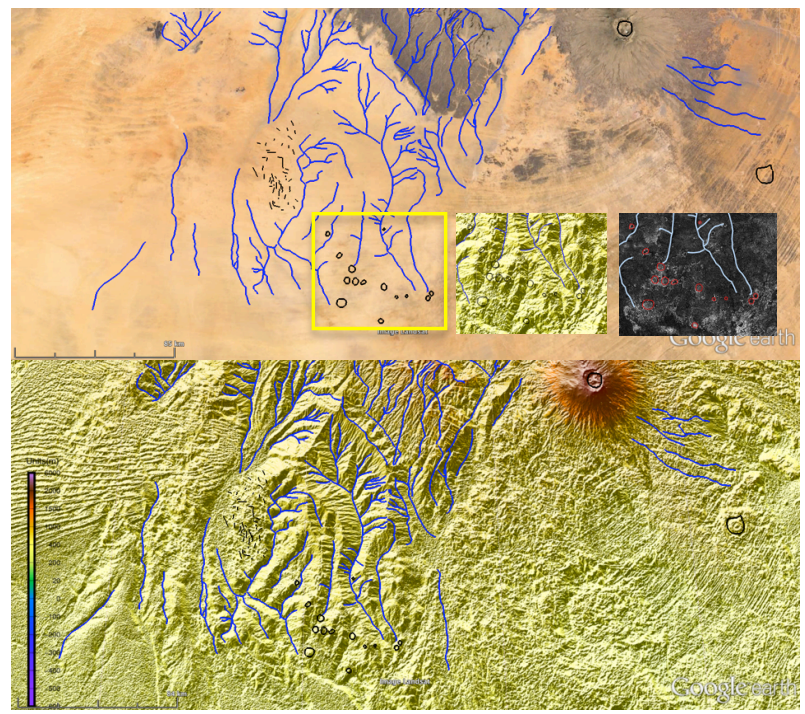

(a) $\operatorname{Part} A$

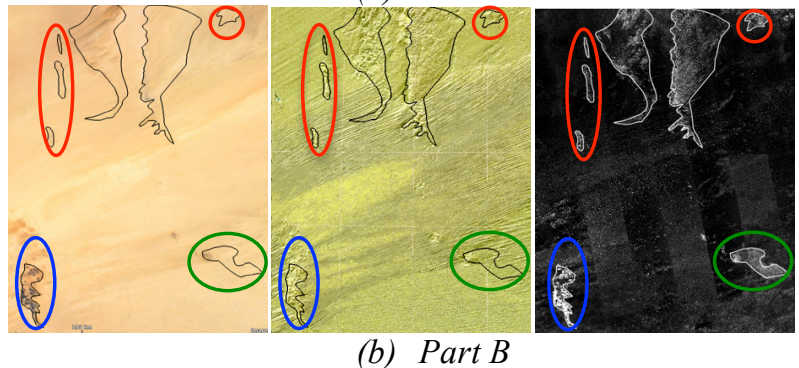

Figure 4. Subsurface features in the Ténéré Desert

\subsection{Comparisons of different DEMs}

The two smaller study areas shown in Fig. 1 are further analysed. Firstly, comparisons between ASTER GDEM and SRTM-C DEM are shown in Fig. 5. Then, we compare ASTER GDEM, SRTM-C and -X band DEMs against ICESat/GLA14 datasets, shown in Fig. 6. Initially, there are about 640 footprints over the 1 degree bin in each track of ICESat, but it is masked with nodata areas of DEMs. The masked footprints of ICESat data are donated as black dots in Fig. 5.

Comparing between Fig. 5(a) and (b), we can see that the main stream is more apparent with more tributaries observed in the SRTM-C DEM, while ASTER GDEM shows higher and nosier elevations, which are affected by severe noise due to the lack of contrast in the stereo image pairs and possible atmospheric sand particles obscuring the surface. There are more small features 
shown in SRTM-C DEM when comparing between Fig. 5(d) and (e), and Fig. 5(f) shows the ASTER GDEM showing bigger differences with SRTM-C DEM in the flat regions rather than in the Plateaus, which may due to penetration happening in flat regions covered by sand.
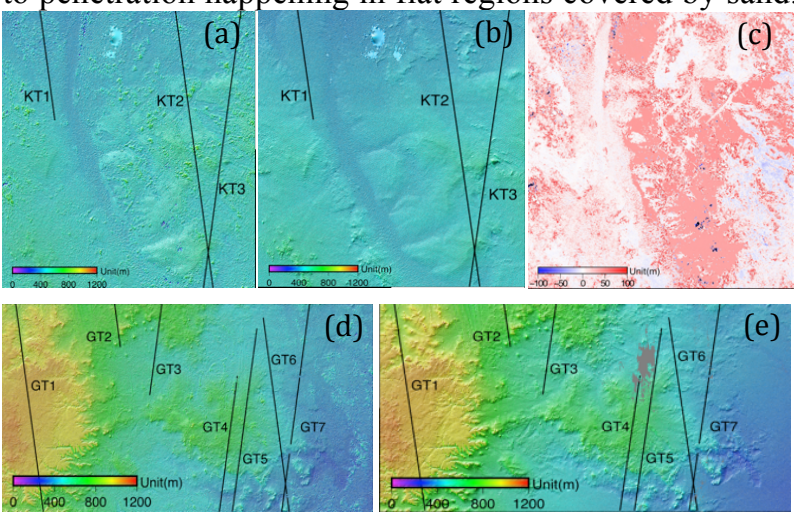

(f)

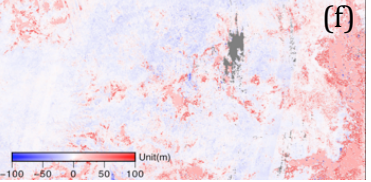

Figure 5. (a)(d) ASTER GDEM, (b)(e)SRTM-C band $D E M$ and (c)(f)height difference between them in the Kufrah River: (a)-(c) and the Gilf Kebir Plateau: (d)-(f).

In order to compare different DEMs quantitatively, we extract the elevations from the re-projected ASTER GDEM, SRTM-C and -X DEM at the location of ICESat footprints. Taking ICESat elevations as references, difference of elevations from different DEMs are shown in Fig. 6. These comparisons confirm that the ASTER GDEM is very noisy in both of the two study sites, and shows 10-23 m higher elevations in the Kufrah River on average. SRTM-C DEM agrees closely with ICESat elevations, but has 2-3 $\mathrm{m}$ positive bias in the Gilf Kebir Plateau region, which may due to steeper slopes in this region. However, SRTM-X DEM has a large negative bias of $\approx 15 \mathrm{~m}$ with ICESat/GLA14 and SRTM-C DEM in Kufrah River, and a negative bias of $\approx 2 \sim 5 \mathrm{~m}$ in the Gilf Kebir Plateau, which appears to be caused by phase adjustment difficulties during InSAR (Interferometric SAR) processing as reported in [10]. Therefore, we can conclude that among these DEMs, SRTM-C DEM appears most suitable to the application of mapping subsurface features.

Then, applying a topographic feature analysis tool in ENVI to SRTM-C DEM to show channels, which are here represented in dark blue colour in Fig. 7(a) and Fig. 8(a). Meanwhile, RGB colour composites are applied to SRTM-C DEM, ASTER GDEM and PALSAR HH image, which are shown in Fig. 7(b) and Fig. 8(b). With the false colour combination of SRTM-C DEM and PALSAR HH image, the results of RGB colour composites show more information, such as some river like features in the Gilf Kebir Plateau, than those of the topographic features analysis.
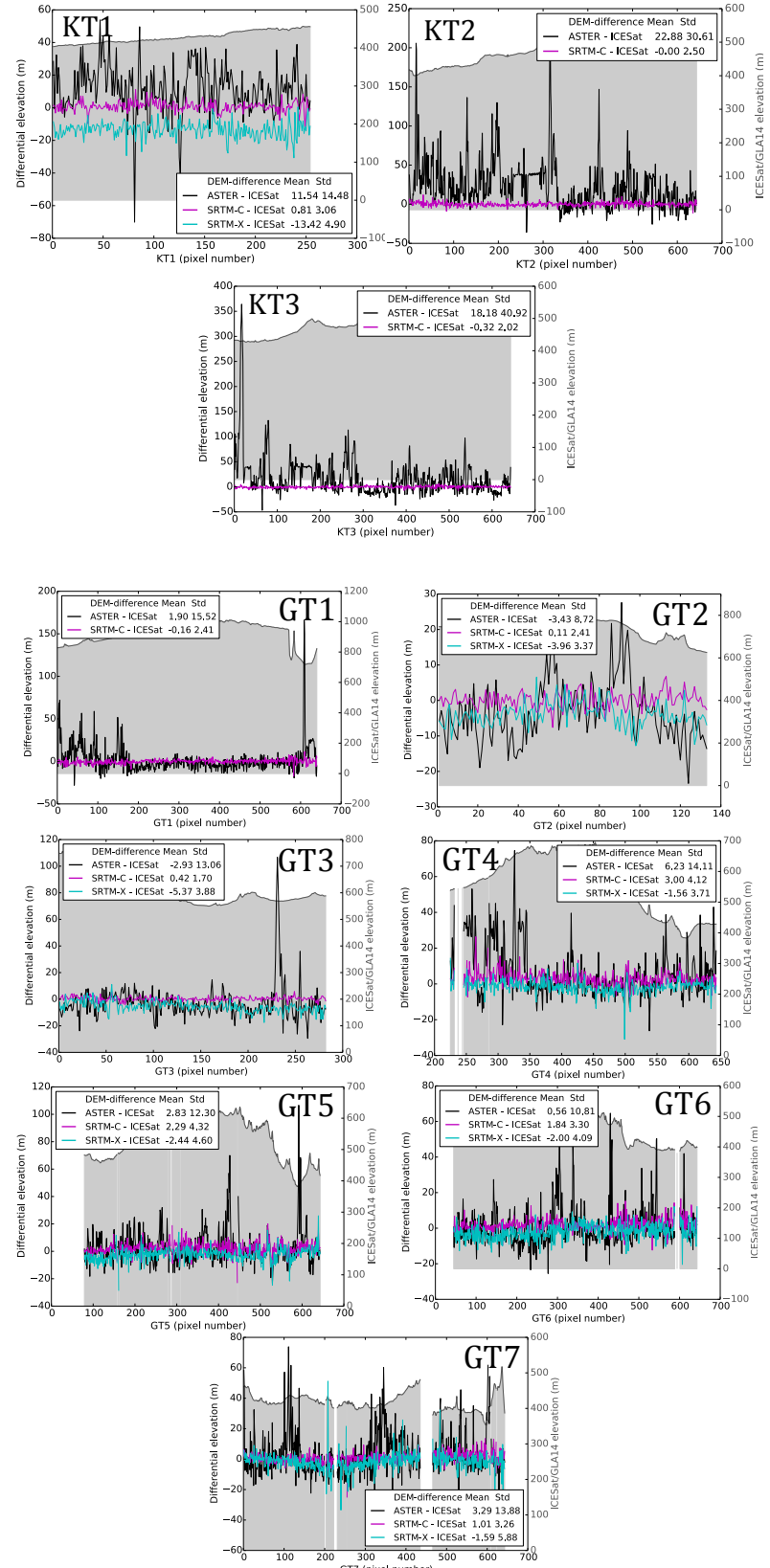

Figure 6. Comparisons between different DEMs at the location of ICESat footprints in the Kufrah River: KT1-3, and in the Gilf Kebir Plateau: GT1-7.
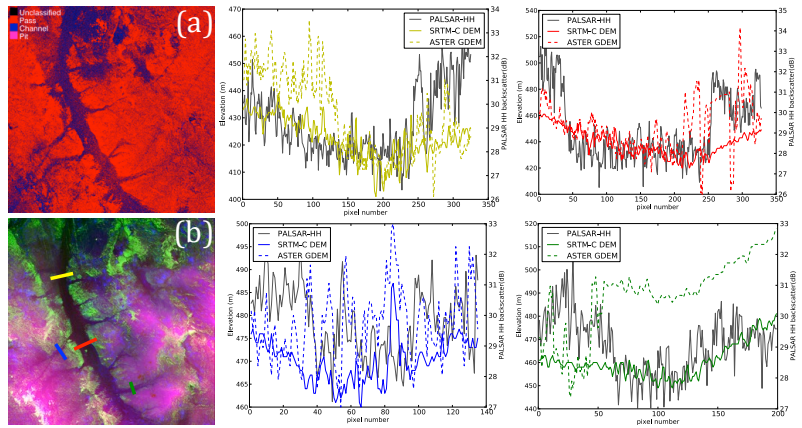

Figure 7. (a) Topographic features analysis, (b) $R G B$ composite, R: SRTM-CDEM, G: PALSAR-HH, B: ASTER GDEM, and transects over the Kufrah river. 
In order to study the effectiveness of the SRTM-C DEM and PALSAR HH images in terms of surface expression of subsurface features, we select several transects across the mainstream and tributaries of the Kufrah River, and across the river like features and circular features in the Gilf Kebir Plateau. These transect profiles are shown in Fig. 7 and Fig. 8. We can see from Fig. 7 that the trend of SRTM-C DEM profile over the main stream and the east tributary agrees closely with the trend of PALSAR $\mathrm{HH}$ backscatter, but with less agreement along the west transect denoted as a blue line in Fig. 7. The profiles of transects (red and green lines) over river like features in the Gilf Kebir Plateau shows similar trends of SRTM-C DEM and PALSAR HH backscatter. Moreover, profiles of a transect across a circular feature show two peaks, which indicate the rim of the circular feature.

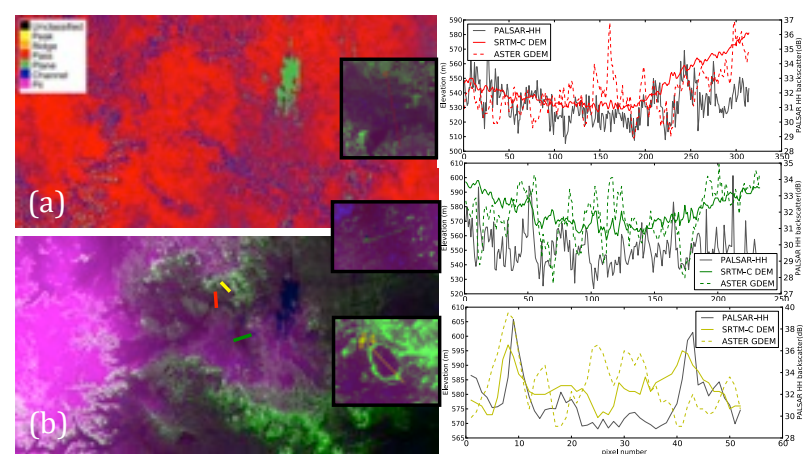

Figure 8. (a) Topographic features analysing, (b) $R G B$ composite, R: SRTM-C DEM, G: PALSAR-HH, B: ASTER GDEM, and transects over the Gilf Kebir Plateau.

\section{CONCLUSIONS}

This study researches into the extraction of subsurface features in the eastern Sahara and Ténéré Desert by using SRTM-C DEM and ALOS/PALSAR HH backscatter. The circular features and small tributaries are easier to be detected from the backscatter, which however is easily affected by similar backscatters from the background. Due to a short baseline, the relative accuracy of SRTM-C DEM is not sufficient to measure the surface expression of penetration depth accurately, but it shows the potential to map the bedrock elevation by using InSAR of lower frequency and longer baseline, such as from ALOS/PALSAR and ALOS-2/PALSAR-2.

Taking ICESat/GLA14 elevations as reference, this study compared different DEMs at the location of the ICESat footprints. SRTM-C DEM and ICESat dataset are shown to be superior to ASTER GDEM in terms of heighting expressions of subsurface features over hyperarid regions. Subsurface features, such as craterlike features and tributaries of Paleo-channels are apparent in SRTM-C DEM while less recognisable in ASTER GDEM v2. SRTM-C DEM agrees closely with ICESat elevation. However, in the study site over Gilf Kebir Plateau, SRTM-C DEM is higher, which might be due to its $30 \mathrm{~m}$ resolution compared with $\approx 70 \mathrm{~m}$ of ICESat. SRTM-X DEM shows a big negative bias compared with ICESat elevations and SRTM-C DEM over the eastern Sahara, which may be due to phase adjustment difficulties [10].

In conclusion, SRTM-C DEM shows the effectiveness of using the DEM to extract subsurface features and indicates the potential to map bedrock elevation by using InSAR-derived DEM of lower frequency. Our future work focuses on generating InSAR-derived DEM from ALOS-2/PALSAR-2, producing and assessing the penetration depth by integrating InSAR-derived DEMs at different frequencies and radar backscatters, and finally validating mapping bedrock elevation where radar penetration is down to bedrock.

\section{ACKNOWLEDGEMENTS}

China Scholarship Council (CSC) and University College London (UCL) jointly sponsor the work. The authors would like to thank the data grant of the 4th ALOS RA (PI No.1488) led by Dr J-R Kim.

\section{REFERENCES}

1. McCauley, J. F., Schaber, G. G., Breed, C. S., et al. (1982). Subsurface Valleys and Geoarcheology of the The eastern Sahara Revealed by Shuttle Radar. Science, 218(4576), 1004-1020.

2. Blom, R. G., Crippen, R. E., and Elachi, C. (1984). Detection of Subsurface Features in SEASAT Radar Images of Means Valley, Mojave Desert, California. Geology, 12(6):346-349.

3. Elachi, C., Roth, L. E., Schaber, G. G. (1984). Spaceborne Radar Subsurface Imaging in Hyperarid Regions, IEEE Trans. on Geosci. and Remote Sens., GE-22(4), 383-388.

4. Paillou, P., Reynard, B., Malézieux, J. M., et al. (2006). An Extended Field of Crater-shaped Structures in the Gilf Kebir Region, Egypt: Observations and Hypotheses about their Origin. Journal of African Earth Sci.. 46(3), 281-299.

5. Paillou, P., Schuster, M., Tooth, S., et al. (2009). Mapping of a Major Paleodrainage System in Eastern Libya Using Orbital Imaging Radar: The The Kufrah River. Earth and Planetary Science Letter, 43(2), 327-333.

6. El-Baz, F. (1998). Sand Accumulation and Groundwater in the Eastern Sahara. Episodes, 21:147-151.

7. Kehl, H., Bornkamm, R. (1993). Landscape ecology and vegetation units of the Western Desert of Egypt. Catena Supplement, 26: 155-178. 
8. Robinson, C. A., El-Baz, F., Al-Saud, T. S. M., et al. (2006). Use of Radar Data to Delineate Palaeodrainage Leading to the Kufra Oasis in the The eastern Sahara. Journal of African Earth Sci. 44(1), 229-240.

9. Website of NASA Distributed Active Archive Center (DAAC) at NSIDC, http://nsidic.org/data/icesat/faq.html\#p9.

10. Marschalk, U., Roth, A., Eineder, M., et al. (2004). Comparison of DEMs Derived from SRTM/X- and C-band. Proc. of 2004 IEEE International Geosci. and Remote Sens. Symposium (IGARSS), (7), 4531-4534.

11. Carabajal, C. C., \& Harding, D. J. (2006). SRTM CBand and ICESat Laser Altimetry Elevation Comparisons as a Function of Tree Cover and Relief. Photogrammetric Engineering \& Remote Sensing, 72(3), 287-298. 